\title{
Original
}

\section{Visible-Light Bactericidal Effect of Silica Gel-supported Porphyrinatoantimony (V) Catalyst on Legionella Species Occurring in the Living Environmental Fields}

\author{
YOSHIYUKI FUEDA ${ }^{1}$, MANABU HASHIMOTO ${ }^{1}$, KAZUNORI NOBUHARA $^{1}$, \\ HARUHIKO YOKOI $^{2}$, YASUHIRO KOMIYA ${ }^{2}$, TSUTOMU SHIRAGAMI ${ }^{2}$, \\ JIN MATSUMOTO ${ }^{2}$, KIMIKO KAWANO ${ }^{3}$, SEN SUZUKI ${ }^{3}$, \\ AND MASAHIDE YASUDA ${ }^{2 *}$
${ }^{1}$ Fuji Silysia Chemical Ltd., 16303-3, Kihara, Hichiya, Hyuga, Miyazaki 883-0062, 2 Department of Applied Chemistry, Faculty of Engineering, University of Miyazaki, Gakuen-Kibanadai, Miyazaki 889-2192, and ${ }^{3}$ Miyazaki Sanitary and Environment Laboratory, Gakuen-Kibanadai, Miyazaki 889-2155, Japan

Received 20 October 2004/Accepted 20 January 2005

In order to develop a bactericidal agent which can operate under visible-light irradiation, silica gel-supported dihydroxo (tetraphenylporphyrinato) antimony (V) catalyst (SbTPP/SiO ${ }_{2}$ ) was prepared. Experiments to reduce concentrations of Legionella species were performed using a cylindrical SbTPP/SiO ${ }_{2}$-photocatalytic bactericidal apparatus in a cooling tower which held $800 \mathrm{~L}$ of water. After 10 days, the concentrations of Legionella species were reduced to less than the detection limit, and these levels were kept until the irradiation was stopped. Also, a photocatalytic bactericidal experiment was conducted with a fountain that was filled with $13 \mathrm{~m}^{3}$ of water. The concentrations of Legionella species were reduced to less than the detection limit 12 days after the $\mathrm{SbTPP} / \mathrm{SiO}_{2}$ catalyst was installed in the fountain receiving sunlight irradiation. The concentrations of Legionella species were kept at less than 30 $\mathrm{CFU} / 100 \mathrm{ml}$ for 3 months until the catalyst was removed from the fountain. Thus, visible-light irradiation of the SbTPP/SiO ${ }_{2}$ catalyst induced a remarkable bactericidal activity against Legionella species in the living environment.

Key words : Bactericidal effect/Legionella species/Dihydroxo (tetraphenylporphyrinato)antimony (V) complex $/ \mathrm{SiO}_{2}$ support/Living environmental fields.

\section{INTRODUCTION}

Legionella pneumophila has drawn much concern since the first outbreak of Legionnaires' disease in Philadelphia in 1976 (Chang and Yu, 1996). Recently, large outbreaks of Legionnaires' disease have been reported in Portugal, Netherlands, and Spain (Correia et al., 2001; Den Boer et al., 2002; Fernández et al., 2002; Lettinga et al., 2002). The

*Corresponding author. Tel : +81-985-58-7314, Fax : + 81-985-58-7315. natural habitats for $L$. pneumophila are a wide range of aquatic bodies including lakes, streams, and artificially constructed aquatic reservoirs such as fountains and cooling-towers.

On the other hand, the photocatalytic treatments have received much attention as an environmentally friendly process to degrade organic compounds in contaminated water (Legrini et al., 1993). From the standpoint of developing a visible-light driven photocatalyst we have focused on the high-valent metalloporphyrins complexes that have a strong absorption in the visible region. We have previously 
reported on the silica gel-supported dihydroxo (tetraphenyl-porphyrinato) antimony (V) (SbTPP/ $\mathrm{SiO}_{2}$ ) which was effective for the photochemical dechlorination of 4-chlorophenol (Shiragami et al., 2003). Moreover, our recent investigation has elucidated that $\mathrm{SbTPP} / \mathrm{SiO}_{2}$ works as bactericidal agent against $E$. coli in aqueous solution under visible light irradiation (Yokoi et al., 2003). In this study, therefore, we will report on the photocatalytic bactericidal activity of the SbTPP/SiO ${ }_{2}$ to reduce Legionella concentrations and our practical experiments involving a cooling tower and public fountain which can be found in our living environment.

\section{MATERIALS AND METHODS}

\section{Instruments}

For the elemental analysis of the catalysts, the catalysts $(2 \mathrm{~g})$ were calcined at $950^{\circ} \mathrm{C}$ for $2 \mathrm{~h}$ and put into a mixture of water $(2 \mathrm{ml})$ and $\mathrm{HF}$ solution $(46 \%$, $10 \mathrm{ml}$ ) and heated at $200^{\circ} \mathrm{C}$ to remove Si component as $\mathrm{SiF}_{4}$. The residual components were dissolved in hot $\mathrm{HNO}_{3}(1 \mathrm{~mol} / \mathrm{L}, 5 \mathrm{ml})$ and subjected to the elemental analysis of Al and Sb on a Shimadzu AA-6200 atomic absorption spectrometer and a Shimadzu ICPS-7500 inductively coupled plasma (ICP) spectrometer, respectively. The atomic absorption analysis of other metals such as $\mathrm{Na}, \mathrm{Ca}, \mathrm{Fe}$ and $\mathrm{Mg}$ metals was performed after the addition of aqueous $\mathrm{HCl}$ solution of $\mathrm{La}_{2} \mathrm{O}_{3}(5 \mathrm{wt} \%)$ as the matrix modifier. Microscopic spectroscopy of the catalysts was performed on an Olympus FV-300 confocal laser scanning microscope (CLSM) equipped with spectrophotometer (STFL 250, Seki Technotron) linked to CLSM with an optical fiber. Light intensity was measured at the wavelength of $420 \mathrm{~nm}$ by a power meter (TQ8210, Advantest).

\section{Preparation of the photocatalyst}

Dihydroxo (tetraphenylporphyrinato) antimony (V) bromide, $\left[\operatorname{SbTPP}(\mathrm{OH})_{2}\right] \mathrm{Br}$, was prepared according to the literature (Andou et al., 2001; Shiragami et al., 1996; Takagi et al., 1997). Into toluene solution (400 $\mathrm{ml}$ ) of [SbTPP $\left.(\mathrm{OH})_{2}\right] \mathrm{Br}$ (170mg), silica-gel powder (p-SiO $;$; 30g, 300mesh, $0.04 \mathrm{mmf}, 429 \mathrm{~m}^{2} / \mathrm{g}$, BW300, Fuji Silysia Chemical Ltd., Japan) was added and then refluxed for $18 \mathrm{~h}$ (Shiragami et al., 2002). The treated silica-gel was filtered, washed with acetone $(100 \mathrm{ml})$, and then dried under reduced pressure to give the $\mathrm{p}-\mathrm{SiO}_{2}$-supported $\left[\mathrm{SbTPP}(\mathrm{OH})_{2}\right]^{+}$catalyst $\left(\mathrm{SbTPP} / \mathrm{p}-\mathrm{SiO}_{2}\right)$ where the content of [SbTPP $\left.(\mathrm{OH})_{2}\right]^{+} \mathrm{Br}^{-}$chromophore was $0.87 \mathrm{wt} \%$ (Fig. 1).

Into $\mathrm{MeOH}$-toluene solution $(1: 4 \mathrm{v} / \mathrm{v}, 500 \mathrm{ml})$ of [SbTPP $\left.(\mathrm{OH})_{2}\right] \mathrm{Br}(35 \mathrm{mg})$, silica gel beads $\left(\mathrm{b}-\mathrm{SiO}_{2}\right.$; $70 \mathrm{~g}, \quad 1.7-4.0 \mathrm{mmf}, 306 \mathrm{~m}^{2} / \mathrm{g}$, CARIACT Q-10, Fuji Silysia Chemical Ltd. Japan) were added and then the solution was made to stand for $18 \mathrm{~h}$. The $\mathrm{MeOH}$ was removed by distillation from the solution. The treated silica gel was filtered, dried at $70^{\circ} \mathrm{C}$, washed with acetone $(200 \mathrm{ml})$, and then dried at $70^{\circ} \mathrm{C}$ to give the $\mathrm{b}-\mathrm{SiO}_{2}$-supported $\left[\operatorname{SbTPP}(\mathrm{OH})_{2}\right]^{+}$catalyst $\left(\mathrm{SbTPP} / \mathrm{b}-\mathrm{SiO}_{2}\right)$ where the content of [SbTPP $\left.(\mathrm{OH})_{2}\right]^{+} \mathrm{Br}^{-}$chromophore was $0.05 w t \%$. The prepared catalyst was identified by the observation of the characteristic fluorescence of SbTPP chromophore by CLSM analysis (Fig. 2).

\section{Photocatalytic sterilization in L-type glass tubes}

The bactericidal activities of the SbTPP/p-SiO ${ }_{2}$ on L. pneumophila were examined in an L-type glass tube in similar manner to the method reported for E. coli (Yokoi et al., 2003). L. pneumophila was isolated from a cooling tower and identified to be Type I by the PCR method using a leg primer. The phosphate buffer $(9 \mathrm{ml}, 100 \mathrm{mmol} / \mathrm{L}, \mathrm{pH} 7.0)$, the cell suspension of L. pneumophila $\left(1.0 \mathrm{ml}\right.$, ca. $10^{6} \mathrm{CFU} /$ $100 \mathrm{ml})$, and $\mathrm{SbTPP} / \mathrm{p}-\mathrm{SiO}_{2}(10 \mathrm{mg})$ were poured into the L-type glass tube (length $18 \mathrm{~cm}$, diameter $1.5 \mathrm{~cm}$ ). The L-type glass tube was set on a reciprocal shaker and irradiated by two fluorescent lamps, 15W each, which were set above the shaker. Light intensity on the surface of the L-type glass tubes was $21 \mathrm{~W} / \mathrm{m}^{2}$ and the reaction temperature was kept constant at $30^{\circ} \mathrm{C}$.

A portion $(0.1 \mathrm{ml})$ of the reaction mixture was directly plated on a selective medium for Legionella
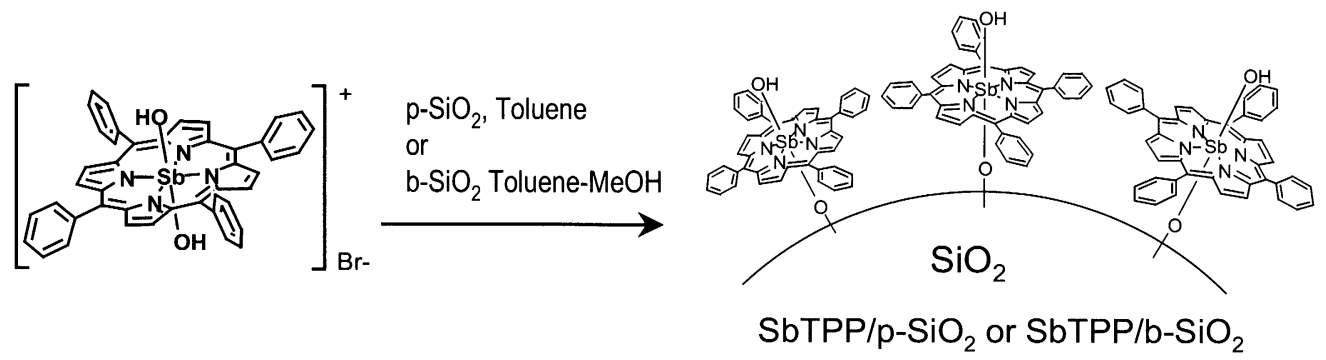

FIG. 1. Preparation of $\mathrm{SbTPP} / \mathrm{p}$ - or b-SiO${ }_{2}$ from the reaction of $\left[\mathrm{SbTPP}(\mathrm{OH})_{2}\right] \mathrm{Br}$ with $\mathrm{SiO}_{2}$. 


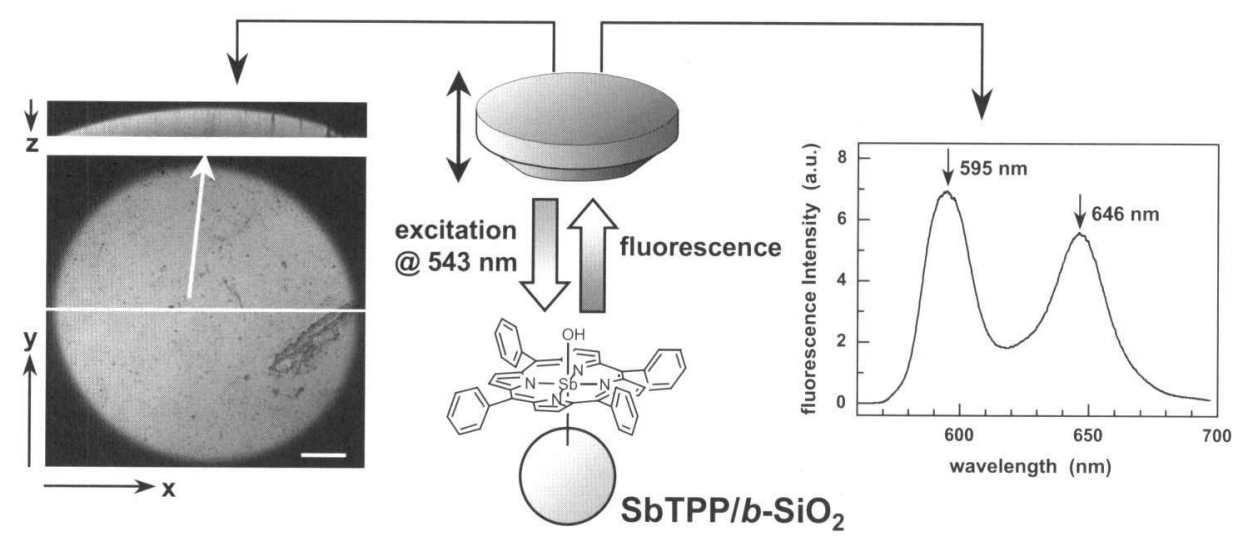

FIG. 2. The imaging and fluorescence spectra of $\mathrm{SbTPP} / \mathrm{b}-\mathrm{SiO}_{2}$ measured on CLSM.

species: WYO $\alpha$ agar medium (Eiken Chemicals Co., $\mathrm{Ltd}$, Japan) consisting of $3 \mathrm{~g}$ of glycine, $5 \mathrm{mg}$ of vancomycin, $10^{6} \mathrm{IU}$ of polymixin $\mathrm{B}$, and $80 \mathrm{mg}$ of amphotericin B. The colonies of L.pneumophila, which appeared after incubation for $7 \mathrm{~d}$ at $36^{\circ} \mathrm{C}$ were counted in three replicate plates.

\section{Practical experiments in a cooling-tower using a cylindrical bactericidal apparatus}

The bactericidal experiment was performed in a cooling tower which was set in a hospital in Miyazaki city, using a cylindrical apparatus $(20 \mathrm{~cm} \phi \times 50 \mathrm{~cm}$, Fig. 3A) consisting of 7 fluorescent lamps (18W, 4.3 $\mathrm{cm} \phi \times 50 \mathrm{~cm})$ and the $\mathrm{SbTPP} / g-\mathrm{SiO}_{2}$ catalyst $(4.0 \mathrm{~kg})$, as shown in Fig. 3B. Water in the holder $(800 \mathrm{~L})$ of the cooling tower was fed to the cylindrical vessel by a pump at $28 \mathrm{~L} / \mathrm{min}$ and then the treated water was returned to the holder. The average retention time was calculated to be $26 \mathrm{~s}$. In the cylindrical vessel, the $\mathrm{SbTPP} / \mathrm{b}-\mathrm{SiO}_{2}$ catalyst was irradiated by visible-light emitted from fluorescent lamps at ambient temperature. The sampling was carried out at the outlet of the apparatus at 3-7 d intervals. At same time, the atmospheric temperatures were recorded as the average values of the highest temperature of Miyazaki city during three days of the sampling day and two days before the sampling day. Viable cell numbers of bacteria that were mostly presumed to be Legionella species were determined as follows. The sample water $(1000 \mathrm{ml})$ was filtrated by membrane filter $(0.45 \mu \mathrm{m}$ HA, Millipore) under reduced pressure. Into the vessel $(100 \mathrm{ml})$ containing the microbes adhering to the membrane filter, an aqueous solution $(5 \mathrm{ml})$ was added and then the vessel was shaken vigorously. Additional aqueous saturated $\mathrm{KCl}$ solution ( $5 \mathrm{ml} ; \mathrm{pH} 2.2$ ) containing $0.2 \mathrm{M} \mathrm{HCl}$ was added to the vessel and which then was shaken and made to stand exactly for $20 \mathrm{~min}$ at room temperature to give the prepared solution. A portion $(0.1 \mathrm{ml})$ of the prepared solution was plated on a WYO $\alpha$ agar medium and incubated for $7 \mathrm{~d}$ at $36^{\circ} \mathrm{C}$. Wet, smooth, and bluish-white colonies were counted on three replicate plates.

\section{Practical experiments in a fountain using a leaf- type bactericidal apparatus}

Practical experiments were performed in a public fountain that was filled with $13 \mathrm{~m}^{3}$ of water in a period from November 8,2002 to October 29,2003 in Miyazaki City. Bactericidal effects were examined using a leaf-type photocatalytic bactericidal apparatus $(20 \mathrm{~cm} \phi \times 2 \mathrm{~cm}$; Fig. $3 \mathrm{C})$ containing the SbTPP/b$\mathrm{SiO}_{2}$ catalyst (80g) under sunlight irradiation, as shown in Fig. 3D. The samplings were arbitrarily carried out at the pool of the fountain at 5-7 d intervals. At same time, the atmospheric temperatures were recorded as mentioned above. Determination of viable
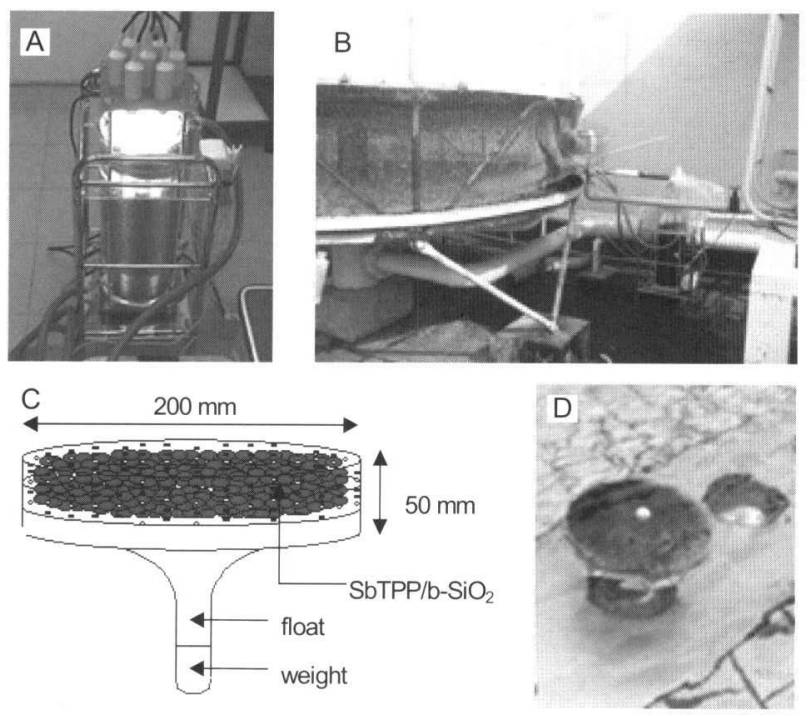

FIG. 3. A cylindrical type photo-bactericidal apparatus (A) was set in the cooling-tower (B). A leaf-type photobactericidal apparatus (C) was installed in the fountain (D). 
cell numbers of Legionella species was carried out in the same manner as in the practical experiments in the cooling-tower.

\section{RESULTS AND DISCUSSION}

\section{Photocatalytic sterilization in L-type glass tube}

The bactericidal effect of $\mathrm{SbTPP} / \mathrm{SiO}_{2}$ on Legionella species in L-type glass tubes was carried out under irradiation by fluorescent lamps. Figure 4 shows time courses of survival ratio of Legionella species in L-type glass tubes where the SbTPP/p$\mathrm{SiO}_{2}$ photocatalyst $(10 \mathrm{mg}$ ) was irradiated by fluorescent lamps in the presence of the cell suspensions

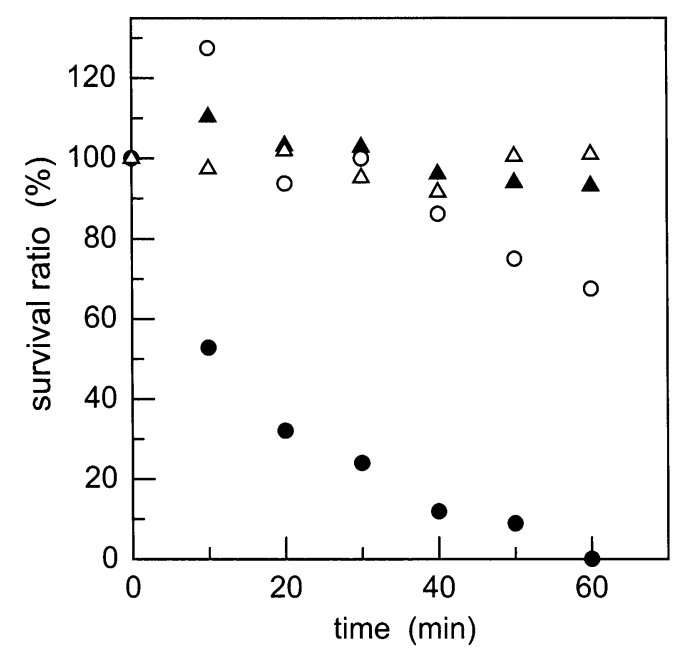

FIG. 4. Bactericidal effect of $\mathrm{SbTPP} / \mathrm{p}-\mathrm{SiO}_{2}$ catalyst on L. pneumophila under irradiation by fluorescent lamp in the presence of the catalyst $(\mathbf{O})$, under the irradiation in the absence of the catalyst $(\bigcirc)$, under dark reaction in the presence of the catalyst $(\boldsymbol{\Delta})$, and under dark reaction in the absence of the catalyst $(\triangle)$.

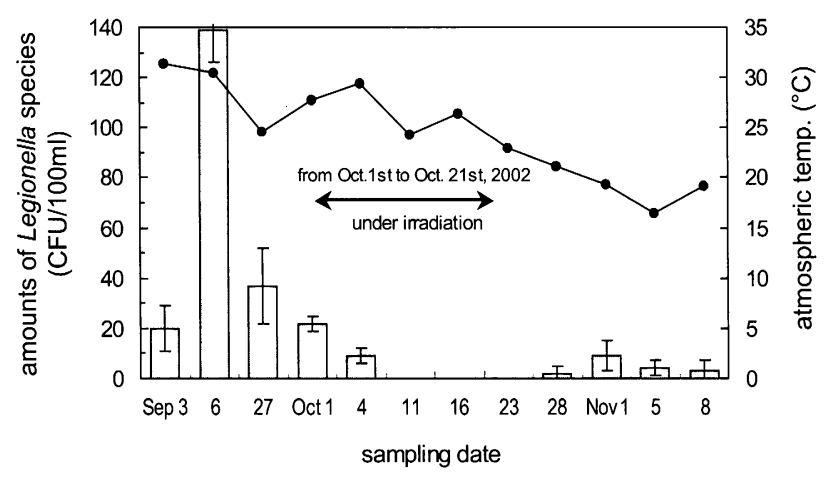

FIG. 5. Time-course plots of the amounts of Legionella species in the cooling-tower along with the atmospheric temperature (1). The cylindrical photo-bactericidal apparatus was operated during October 1 to October 21, 2002. Conditions; catalyst: $4 \mathrm{~kg}$, contents of water: ca. $800 \mathrm{~L}$, flow rate: $28 \mathrm{~L} / \mathrm{min}$, and the average retention time: $26 \mathrm{~s}$.
$(10 \mathrm{ml})$. Upon irradiation for $60 \mathrm{~min}$ in the presence of the SbTPP/p-SiO ${ }_{2}$, the concentration of Legionella species apparently decreased from the initial concentration $\left(6.4 \times 10^{5} \mathrm{CFU} / 100 \mathrm{ml}\right)$ to $4 \times 10^{3} \mathrm{CFU} / 100 \mathrm{ml}$ : its survival ratio was $0.6 \%$. In the control experiments under irradiation in the absence of SbTPP/p-SiO ${ }_{2}$, under dark conditions in the presence of SbTPP/p-SiO${ }_{2}$, and under dark conditions in the absence of $\mathrm{SbTPP} / \mathrm{p}-\mathrm{SiO}_{2}$, nearly the initial concentration of Legionella species was kept. Thus, it is confirmed that $\mathrm{SbTPP} / \mathrm{p}-\mathrm{SiO}_{2}$ has the photocatalytic activity to reduce concentrations of Legionella species.

\section{Practical experiments in the cooling-tower}

The bactericidal effect of SbTPP/b-SiO ${ }_{2}$ was substantiated in the practical experiments at a coolingtower using a cylindrical photocatalytic bactericidal apparatus (Fig. 3A). Under the conditions without any bactericidal treatments, Legionella species were found in the range of 20 to $139 \mathrm{CFU} / 100 \mathrm{ml}$ in the holder of the cooling tower, as shown in Fig. 5. After the bactericidal apparatus was operated for 4 days, the concentration of Legionella species was reduced to $22 \mathrm{CFU} / 100 \mathrm{ml}$. Further operation reduced the concentrations of Legionella species to reach less than the detection limit, and these levels were kept until the irradiation was stopped. Seven days after the irradiation was stopped, detectable amounts of Legionella species appeared. Thus, bactericidal effects of SbTPP/b-SiO ${ }_{2}$ were practically confirmed in practical experiments involving cooling tower.

\section{Practical experiments in the fountain}

The preliminary concentrations of Legionella species naturally occurring in a public fountain were measured for 7 months from November, 2002 to May, 2003 under the conditions without any bactericidal treatments. Figure $6 \mathrm{~A}$ showed the time-course plots of the concentrations of Legionella species, which were strongly dependent on atmospheric temperature. As the atmospheric temperature increased, the concentrations of Legionella species also increased, as shown in Fig. 7. Concentrations of Legionella species exceeded 500CFU/100ml in some samples when the atmospheric temperature went over $25^{\circ} \mathrm{C}$.

Practical bactericidal experiments were performed using a leaf-type photo bactericidal apparatus containing $80 \mathrm{~g}$ of $\mathrm{SbTPP} / \mathrm{b}-\mathrm{SiO}_{2}$, which was set into the fountain under sunlight irradiation during the period from May 28, 2003 to August 25, 2003. The concentration of Legionella species were reduced to less than the detection limit, $12 \mathrm{~d}$ after the leaf-type apparatus was installed to the fountain.

The concentrations of Legionella species were 
continuously kept at less than $30 \mathrm{CFU} / 100 \mathrm{ml}$ until the leaf-type apparatus was removed from the fountain on August 25 (Fig. 6B). After the removal of the leaftype apparatus, the concentrations of Legionella species were gradually increased to reach $100 \mathrm{CFU/}$ $100 \mathrm{ml}$, the environmental quality standard, $42 \mathrm{~d}$ after the removal of the leaf-type apparatus, as shown in Fig. 6B. In these practical experiments, it is noteworthy that $80 \mathrm{~g}$ of $\mathrm{SbTPP} / \mathrm{b}-\mathrm{SiO}_{2}$ catalyst, i.e. $40 \mathrm{mg}$ of $\left[\mathrm{SbTPP}(\mathrm{OH})_{2}\right]^{+} \mathrm{Br}^{-}$chromophore, kept the concentration of Legionella species in $13 \mathrm{~m}^{3}$ of water below $100 \mathrm{CFU} / 100 \mathrm{ml}$ for $120 \mathrm{~d}$.

\section{Analysis of the catalyst}

Elemental analysis of the catalyst before and after its use was performed by atomic absorption and ICP (Table 1). Before being used, the Sb content in $\mathrm{SbTPP} / \mathrm{b}-\mathrm{SiO}_{2}$ was measured to be $80 \mathrm{ppm}$, which showed good agreement with the $\mathrm{Sb}$ content (72ppm) calculated for the $0.05 \mathrm{wt} \%$ of SbTPP content in the catalyst. Contents of metals other than $\mathrm{Sb}$ in the catalyst were as follows: $67(\mathrm{Na}), 6(\mathrm{Mg}), 29$ (Al), $12(\mathrm{Ca})$, and $0.2 \mathrm{ppm}(\mathrm{Fe})$. After being used in the practical experiment for 3 months in the fountain, the $\mathrm{Sb}$ content deceased from $80 \mathrm{ppm}$ to $17 \mathrm{ppm}$. On
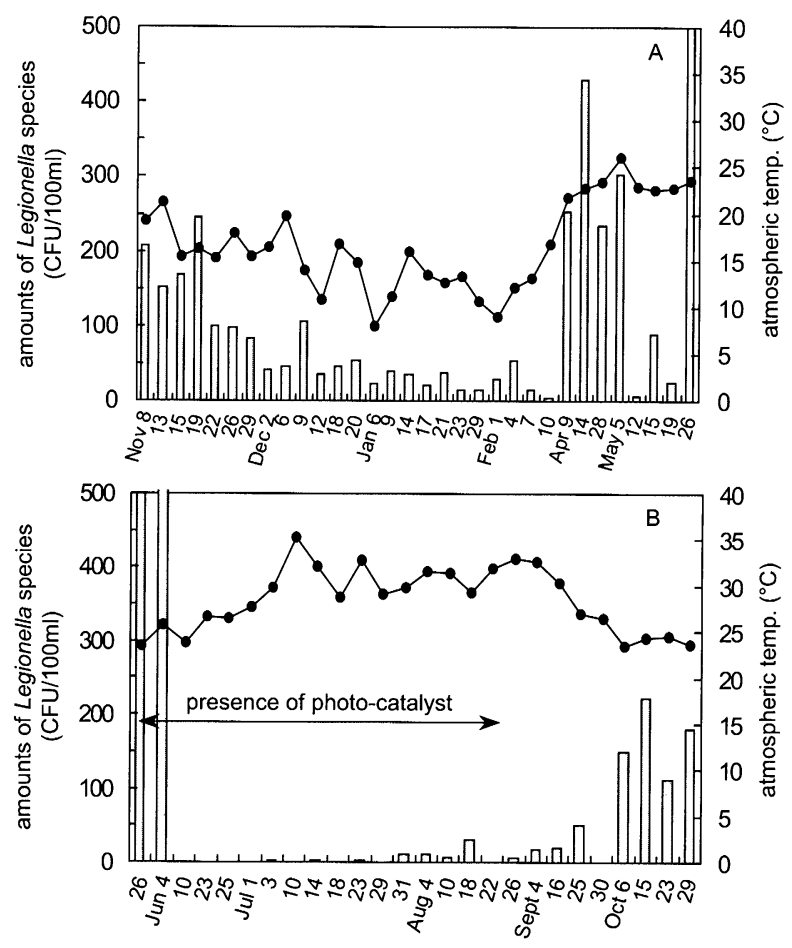

FIG. 6. (A) Survey of Legionella species found in the fountain from November 26, 2002 to May. 26, 2003. (B) the bactericidal experiment of Legionella species was performed using a leaf-type photo-bactericidal apparatus containing $\mathrm{SbTPP} / \mathrm{SiO}_{2}(80 \mathrm{~g})$ under sunlight irradiation from May 26 to Aug. 22, 2003.

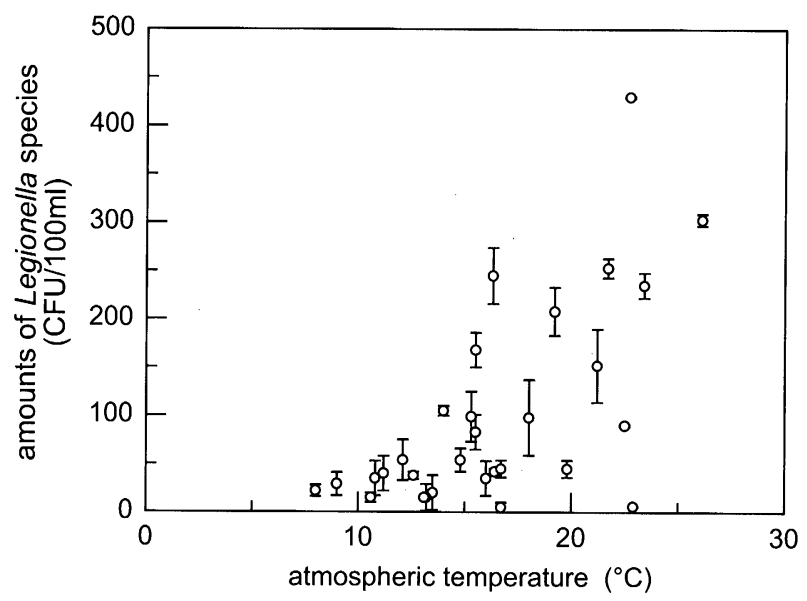

FIG. 7. Dependence of amounts of Legionella species naturally occurring in the fountain on the atmospheric temperature.

the other hand, $\mathrm{Na}, \mathrm{Mg}, \mathrm{Al}$, and Ca largely increased, resulting in the occurrence of the ion-absorption on $\mathrm{SiO}_{2}$. Moreover, the analysis of the SbTPP/b-SiO catalyst used for the practical experiment in the fountain was performed by CLSM (Fig. 8). It was found that the fluorescence come from the surface of the catalyst kept a shape similar to that of the original catalyst, but the intensity was weaker compared with the original spectra of $\mathrm{SbTPP} / \mathrm{b}-\mathrm{SiO}_{2}$. On the other hand, the fluorescence from the inside of the catalyst maintained its original intensity. Therefore, it is suggested that $\left[\operatorname{SbTPP}(\mathrm{OH})_{2}\right]^{+}$chromophore was eliminated from the surface of catalyst. Irradiation of fluorescent light on the SbTPP/b-SiO ${ }_{2}$ catalyst in deionized water did not entirely cause the spectral change and decrease of Sb-amounts. Therefore, it is strongly suggested that the cationic $\left[\operatorname{SbTPP}(\mathrm{OH})_{2}\right]^{+}$ chromophore was exchanged with alkali metal ions in the bulk water on the surface of catalyst under irradiation.

TABLE 1. Elemental analysis of $\mathrm{SbTPP} / \mathrm{SiO}_{2}{ }^{a}$

\begin{tabular}{ccccccc}
\hline \multirow{2}{*}{ Item } & \multicolumn{7}{c}{ Element $^{b}$} \\
\cline { 2 - 8 } & $\mathrm{Na}$ & $\mathrm{Mg}$ & $\mathrm{Al}$ & $\mathrm{Ca}$ & $\mathrm{Fe}$ & $\mathrm{Sb}$ \\
\hline Before Use & 67 & 6 & 29 & 12 & 0.2 & $80^{\circ}$ \\
\hline After Use & 208 & 79 & 89 & 316 & 0.5 & 13 \\
\hline
\end{tabular}

${ }^{a} \mathrm{SbTPP} / \mathrm{SiO}_{2}$ photo-catalyst of which the SbTPP content was 0.05 wt\%.

${ }^{b}$ Content of elements in ppm.

'This value showed good agreement to the $\mathrm{Sb}$ content (72ppm) of $0.05 w t \%$ of SbTPP.

${ }^{a}$ The $\mathrm{SbTPP} / b-\mathrm{SiO}_{2}$ catalyst after the practical experiment in the fountain for 3 months.

Water of the fountain involved the following minerals: $\mathrm{Al}=$ 2, $\mathrm{Na}=3, \mathrm{Ca}=18, \mathrm{Fe}=0.5, \mathrm{Mg}=9, \mathrm{Sb}<0.04 \mathrm{ppm}$. 


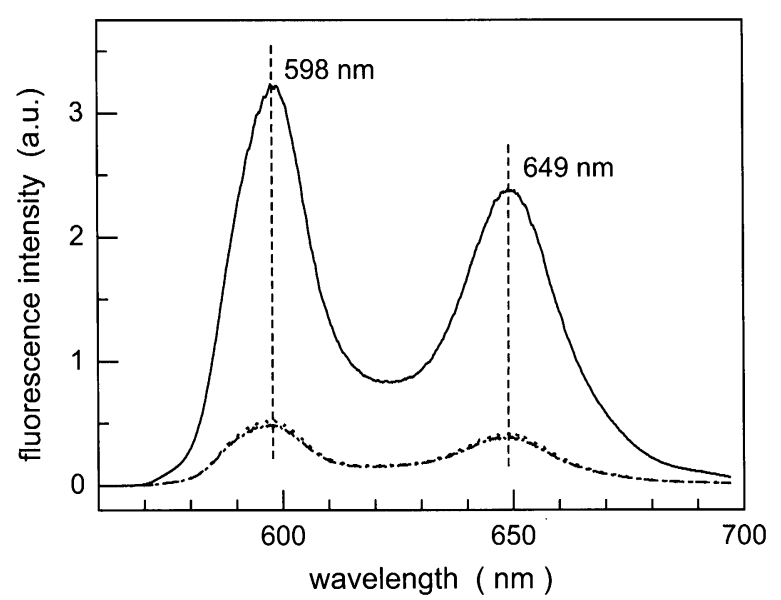

FIG. 8. CLSM fluorescence spectra of $\mathrm{SbTPP} / b-\mathrm{SiO}_{2}$ before (solid line) and after use for the practical experiment in the fountain: Spectra of the surface (broken line) of the catalyst after use.

In conclusion, the SbTPP/b-SiO ${ }_{2}$ catalyst operated effectively to reduce Legionella concentrations under visible-light irradiation in the living environments. It is well known that the photocatalytic process by titanium dioxide $\left(\mathrm{TiO}_{2}\right)$ has been widely applied to the disinfection and sterilization (Kühn et al., 2003; Matsunaga et al., 1985; Saito et al., 1992; Theurich et al., 1996) as well as treatment of wastewater (Legrini et al., 1993). However, $\mathrm{TiO}_{2}$ has only weak absorption in the visible region. It is, therefore, expected that the present visible-light bactericidal technique by the SbTPP/b-SiO ${ }_{2}$ catalyst will be one of the powerful methods to sterilize aquatic bodies of harmful microbes.

\section{ACKNOWLEDGMENT}

This work was supported by a Cooperative Project of Miyazaki prefecture in Japan and by a Grant-in-Aid for Scientific Research (No.14050079, Scientific Research in Priority Areas 417) from the Ministry of Education, Science, Sports, and Culture. We also thank Ms Eriko Masuda and Mr. Koji Nakashima for performing sampling in the cooling tower and fountain.

\section{REFERENCES}

Andou, Y., Shiragami, T., Shima, K., and Yasuda, M. (2001) Synthesis and fluorescence study of a (2-naphthoxy) polyoxalkoxyantimony $(\mathrm{V})$ tetraphenylporpyrin complex. J. Photochem. Photobiol., A, Chem., 147, 191-197.

Chang, F.-Y., and Yu, V. L. (1996) Legionella infection. In Fishman's Pulmonary Diseases and Disorders, vol 2, 3rd edn. (Fishman, A. P., Elias, J. A., Fishman, J. A., Grippi, M. A., Kaiser, L. R., and Senior, R., ed.), pp. 945-949, McGraw Hill, New York.
Correia, A. M., Goncalves, G., Reis, J., Cruz, J. M., and Castro e Freitas, J. A. (2001) An outbreak of legionnaires' disease in a municipality in northern Portugal. Eurosurveillance, 6, 121-124.

Den Boer, J. W., Yzerman, E. P. F., Schellekens, J., Lettinga, K. D., Boshuizen, H. C., Steenbergen, J. E. V., Bpsman, A., Van den Hof, S., Van Vliet, H. A., Peeters, M. F., Van Ketel, R. J., Speelman, P., Kool, J. L., and ConynVan Spaendonck, M. A. E. (2002) A large outbreak of Legionnaires' disease at a flower show, the Netherlands, 1999. Emerg. Infect. Dis., 8, 37-43.

Fernández, J.A., López, P., Orozco, D., and Merino, J. (2002) Clinical Study of an Outbreak of Legionnaire's Disease in Alcoy, Southeastern Spain. Eur. J. Clin. Microbiol. Infect. Dis. , 21, 729-735.

Kühn, K. P., Chaberny, I. F., Massholder, K., Sticker, M., Benz, V. W., Sonntag, H.-G., and Erdinger, L. (2003) Disinfection of surfaces by photocatalytic oxidation with titanium dioxide and UV light. Chemosphere, 53, 71-77.

Legrini O., Iliveros E. and Braun A. M. B. (1993) Photochemical process for water treatment. Chem. Rev., 93, 671-689.

Lettinga, K. D., Verbon, A., Weverling, G.-J., Schellekenes, J. F. P., Den Boer, J. W. Yzerman, E.P.F., Prins, J., Boersma, W. G., van Ketel, R. J., Prins, J. M., and Speelman, P. (2002) Legionnaires' Disease at a Dutch Flower Show: Prognostic Factors and Impact of Therapy. Emerg. Infect. Dis., 8, 1448-1454.

Matsunaga, T., Tomoda, R., Nakajima, T., and Wake, H. (1985) Photoelectrochemical sterilization of microbial cells by semiconductor powders. FEMS Microbiol. Lett., 29, 211-214.

Saito, T., Iwase, T., Horie, J., and Morioka, T. (1992) Mode of photocatalytic bactericidal action of powdered semiconductor $\mathrm{TiO}_{2}$ on mutans streptococci. J. Photochem. Photobiol., 14, 369-379.

Shiragami, T., Kubomura, K., Ishibashi, D., and Inoue, $\mathrm{H}$. (1996) Efficient photochemical oxygenation of cyclohexene with water as an oxygen donor sensitized by dimethoxy-coordinated tetraphenylporphyrinatoantimony (V). J. Am. Chem. Soc., 118, 6311-6312.

Shiragami, T., Shimizu, Y., Hinoue, K., Fueta, Y., Nobuhara, K., Akazaki, I., and Yasuda, M. (2003) Silica gelsupported porphyrinatoanitimony (V) complex acting as visible-light driven photocatalyst for dechlorination of chlorophenols in aqueous solution. J.Photochem. Photobiol., A, Chem., 156, 115-119.

Takagi S., Suzuki M., Shiragami T. and Inoue H. (1997) Photochemical P-450 oxygenation of cyclohexene with water sensitized by dihydroxy-coordinated (tetraphenylporphyrinato) antimony (V) hexafluorophosphate. J. Am. Chem. Soc., 119, 8712-8713.

Theurich, J., Lindner, M., and Bahnemann, D.W. (1996) Photocatalytic degradation of 4-chlorophenol in aerated aqueous titanium dioxide suspensions: Kinetic and mechanistic study. Langmuir, 12, 6368-6376.

Yokoi, H., Shiragami, T., Hirose, J., Kawauchi, T., Hinoue, K., Fueda, Y., Nobuhara K., Akazaki, I., and Yasuda, M. (2003) Bactericidal effect of a silica gel-supported porphyrinatoantimony $(\mathrm{V})$ complex under visible light irradiation. World J. Microbiol. Biotechnol., 19, 559-563. 